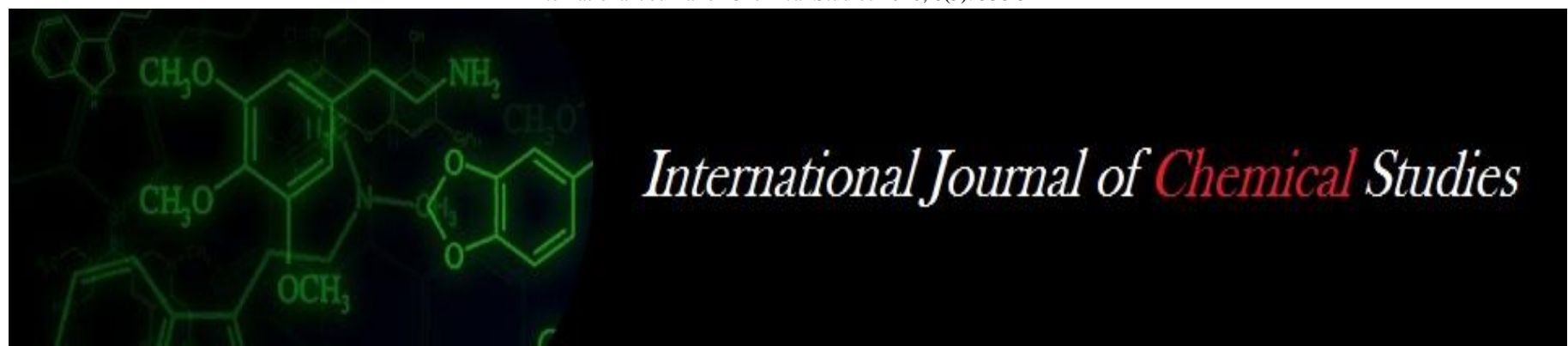

P-ISSN: 2349-8528

E-ISSN: 2321-4902

www.chemijournal.com

IJCS 2020; 8(5): 538-542

(C) 2020 IJCS

Received: 05-06-2020

Accepted: 06-08-2020

Kairovin Lakra

Research Scholar, Department of Agronomy, CSAUAT, Kanpur,

Uttar Pradesh, India

Karam Husain

Professor, Department of Agronomy, CSAUAT, Kanpur,

Uttar Pradesh, India

Corresponding Author:

Kairovin Lakra

Research Scholar, Department of

Agronomy, CSAUAT, Kanpur,

Uttar Pradesh, India

\section{Effect of irrigation and weed management practice on available nutrients, nutrient concentration and their uptake by weeds and wheat}

\author{
Kairovin Lakra and Karam Husain
}

DOI: https://doi.org/10.22271/chemi.2020.v8.i5h.10350

\begin{abstract}
A field experiment was conducted in sandy loam soil during winter season of 2017-18 and 2018-19. Significantly the lowest weed biomass production, highest available nutrients in soil and the maximum $\mathrm{N}$ and $\mathrm{K}$ content in weeds and crop was recorded with the application of irrigation at CRI+ active tillering stage. Whereas, irrigation at CRI+jointing+ booting+ flowering+milking stage was recorded maximum $\mathrm{P}$ content. Application of broadway (carfentrazone ethyl 20\% + sulfosulfuron 25\%WG) $100 \mathrm{~g}$ a.i. ha ${ }^{-1}$ at 35 DAS recorded significantly lowest weed biomass and the highest nutrient content in weeds and crop. Application of irrigation at CRI+jointing+ booting+ flowering+milking stage was recorded significantly the highest nutrients depletion by weeds and their uptake by crop. Significantly the lowest nutrients depletion by weed and their highest uptake of crop and the maximum available nutrients in soil were recorded with the application of broadway (carfentrazone ethyl 20\% + sulfosulfuron 25\%WG) $100 \mathrm{~g}$ a.i. $\mathrm{ha}^{-1}$ at 35 DAS. Grain $\left(9.79 \mathrm{~kg} \mathrm{ha}^{-1}\right)$ and straw yield $\left(4.54 \mathrm{~kg} \mathrm{ha}^{-1}\right)$ will be reduced by an increased in unit of nutrients depletion by weeds.
\end{abstract}

Keywords: Available nutrients, irrigation, herbicides, nutrient content, weed

\section{Introduction}

Wheat (Triticum aestivum L.) is dominant crop in the temperate countries not only for human food, but also for livestock feed. Productivity of wheat is governed by many factors, but one of the most serious and less noticed causes of low yield is the presence of weeds (Kaur and Singh, 2019) ${ }^{[1]}$. Among various factors that affect the yield of wheat, availability of water and weed management are of supreme importance. Water is a key input for all recommended agronomic practices and therefore efficient utilization of irrigation water is essential (Verma $e t$ al., 2015) ${ }^{[21]}$. Weeds compete with crops for water, nutrients and other growth factors, and in absence of an effective control measures, weeds remove considerable quantity of applied nutrients resulting loss in yield and conditions become severe under its scarcity (Sangwan et al., (2019) ${ }^{[12]}$ and Zargar et al., (2020) ${ }^{[22]}$. The yield increases significantly with increase in the level of irrigations (Verma et al., $2017^{[20]}$ and Maurya et al., 2017) ${ }^{[8]}$. Nadeem et al. (2010) ${ }^{[10]}$ reported increase in weed population and their dry weight with increase in irrigation levels. Singh et al. (2019) ${ }^{[13]}$ found that the nutrients uptake by the crop was reduced significantly when the weeds are allowed to grow throughout the crop growing season. Available nutrients in soil were increased under weed management treatments than weedy condition (Singh et al., 2017) ${ }^{[15]}$. Necessity of adequate weed control treatments and timely water supply in crop production through irrigation scheduling is present demand to save water, increases water productivity, nutrients uptake and their availability in soil. Keeping above facts in mind, the present study entitled 'effect of irrigation and weed management practice on available nutrients, nutrient concentration and their uptake by weeds and wheat' was undertaken.

\section{Materials and Methods}

The field experiment was conducted during winter (Rabi) season of 2017-18 and 2018-19 at Students Instructional Farm of Chandra Shekhar Azad University of Agriculture \& Technology, Kanpur. (U.P). 
It is situated at an elevation of 125.9 meter above mean sea level $26^{\circ} 20^{\prime \prime} 35^{\prime \prime}$ North latitude and $80^{\circ} 18 ' 35^{\prime \prime}$ East longitude of Indo-Gangetic Plain in the Central part of Uttar Pradesh. The soil of experimental site is sandy loam, $\mathrm{pH}$ (7.1), low in OC $(0.35 \%)$, available nitrogen $\left(172.4 \mathrm{~kg} \mathrm{ha}^{-1}\right)$, sulphur $(15.7$ $\left.\mathrm{kg} \mathrm{ha}{ }^{-1}\right)$ and zinc $(0.456 \mathrm{ppm})$, and medium in available phosphorus (12.8 $\mathrm{kg} \mathrm{ha}^{-1}$ ) and potassium (156.5 $\left.\mathrm{kg} \mathrm{ha}^{-1}\right)$. The experiment was laid out in Split Plot Design and replicated four times having 32 treatment combinations. The wheat variety 'K-9423' was sown at row distance of $22.5 \mathrm{~cm}$ by opening slits with seed-drill machine. Treatments consisted of four irrigation schedule viz. irrigation at CRI and active tillering stage $\left(\mathrm{I}_{1}\right)$, irrigation at CRI + jointing + booting $\left(\mathrm{I}_{2}\right)$, CRI + active tillering + booting + flowering stage $\left(\mathrm{I}_{3}\right)$ and irrigation at CRI + jointing + booting + flowering + milking stage $\left(\mathrm{I}_{4}\right)$ were assigned to main plots and weed management practices viz. $\mathrm{W}_{1}$-weedy check, $\mathrm{W}_{2}$-two hand weeding at 20 and $40 \mathrm{DAS}, \mathrm{W}_{3}$-sulfosulfuron $25 \mathrm{~g} \mathrm{ha}^{-1}$ at $35 \mathrm{DAS}, \mathrm{W}_{4^{-}}$ pendimethalin (pre-em) $f b$ WCPL-15, $400 \mathrm{~g} \mathrm{ha}^{-1}$ at 35 DAS, $\mathrm{W}_{5^{-}}$broadway (carfentrazone ethyl $20 \%+$ sulfosulfuron 25\%WG) $100 \mathrm{~g}$ a.i. ha ${ }^{-1}$ at 35 DAS, W $6^{-}$halauxafen + penxasulam $23.5 \%, 75 \mathrm{~g}$ a.i. ha ${ }^{-1}$ at $35 \mathrm{DAS}, \mathrm{W}_{7}$ - halauxafen methyl $1.21 \% \mathrm{w} / \mathrm{w}+$ fluroxypyr at 35 DAS and $\mathrm{W}_{8^{-}}$ clodinafop- propargyl $15 \%$ + metsulfuron $1 \% 400 \mathrm{~g}$ a.i. ha ${ }^{-1}$ 35 DAS were allocated to sub plots. The experimental crop was sown in lines $22.5 \mathrm{~cm}$ apart using $100 \mathrm{~kg} \mathrm{ha}^{-1}$ seed by opening slits with seed-drill machine. A uniform recommended dose of $150 \mathrm{~kg} \mathrm{~N}, 75 \mathrm{~kg} \mathrm{P}_{2} \mathrm{O}_{5}$ and $75 \mathrm{~kg} \mathrm{~K}_{2} \mathrm{O}$ $\mathrm{ha}^{-1}$ was applied to crop through urea, DAP and murate of potash, respectively. Half amount of nitrogen and full dose of phosphorus and potash were applied as basal at the time of sowing, $1 / 4$ part of nitrogen was top dressed after first irrigation and remaining $1 / 4$ part of nitrogen was top dress at spike initiation stage. Weed management practices and irrigations were applied as per treatment. General crop management practices were followed. Data on weed was recorded from an area enclosed in the quadrate of $0.25 \mathrm{~m}^{-2}$ randomly selected at three places in each plot. Oven dry weight of weeds was recorded. Grain and straw yield was recorded at harvest were studied. The nutrients content and their depletion by weeds were worked out at 60 days after sowing. Available nutrients in soil and nutrient contents in crop were determined as per the standard procedures at harvest and the uptake values were worked out. Nutrient uptake $\left(\mathrm{kg} \mathrm{ha}^{-1}\right)$ was calculated by multiplying their nutrient concentration with weed biomass and crop yield. The experimental data were analyzed statistically and were interpreted.

\section{Results and Discussion \\ Weed dry weight}

Dry weight of weeds significantly affected by irrigation and weed management practices (Table 1). Significantly the lowest dry weight of weed was recorded with application of irrigation at CRI+ active tillering stage $\left(\mathrm{I}_{1}\right)$ over irrigation at CRI+ active tillering+ booting+ flowering $\left(\mathrm{I}_{3}\right)$ and irrigation CRI+jointing+booting+flowering+milking stage $\left(\mathrm{I}_{4}\right)$ and it was at par with irrigation at CRI+ jointing+booting $\left(\mathrm{I}_{2}\right)$. The decrease in dry weight of weeds at lower rate of irrigation resulted from the least availability of moisture (Verma et al., 2015) ${ }^{[21]}$, which provides inadequate growing environment to weeds (Verma et al., 2008) ${ }^{[17]}$. Application of broadway (carfentrazone ethyl 20\% + sulfosulfuron 25\%WG) $100 \mathrm{~g}$ a.i. $\mathrm{ha}^{-1}$ at 35 DAS caused significant reduction in dry weight of weeds over other herbicidal treatments. These results are corroborated with findings of Singh et al. (2009) ${ }^{[14]}$.

\section{Grain and straw yield}

Irrigation at CRI+jointing+booting+flowering+milking stage resulted into significantly the highest grain and straw yield followed by $I_{3}, I_{2}$ and $I_{1}$, respectively. The better development of crop under irrigated treatments was a result of better moisture availability, which maintained the internal water balance of the plant (Verma et al., $2013^{[18]}$, Kumar et al., $2019{ }^{\text {[7] }}$ and Dhaliwal et al., 2020) [1]. Among weed management practices, application of broadway (carfentrazone ethyl 20\% + sulfosulfuron 25\%WG) $100 \mathrm{~g}$ a.i. $\mathrm{ha}^{-1}$ at 35 DAS resulted significantly the highest grain and straw yield as compared to rest of the herbicidal treatments. The reason for higher values on growth parameter can be discussed in the light of fact that crop under this treatment had comparatively less weed competition. The reduction in weed competition in wheat by the use of herbicides or hand weeding not only favoured the crop growth with abundant availability of moisture, nutrients, light and space, but also reduced the overall weed interference, facilitating vigorous growth and development of crop plants and finally produce more grain and straw yield of wheat (Singh et al., 2017) ${ }^{[16] \text {. }}$

\section{Nutrient content and their depletion by weeds}

The main effect of irrigation and weed management practices on $\mathrm{N}, \mathrm{P}$ and $\mathrm{K}$ concentration in weeds was not significant (Table 1). The $\mathrm{N}$ and $\mathrm{K}$ content in weeds were decreased with increasing number of irrigation and moisture availability was mainly due to dilution effect of these nutrients. Whereas, $\mathrm{P}$ content was increased with increasing levels of irrigation. The $\mathrm{N}, \mathrm{P}$ and $\mathrm{K}$ content in weeds are increased with the application of herbicides as compared to weedy check. The highest nutrient content in weeds was observed under broadway (carfentrazone ethyl 20\% + sulfosulfuron 25\%WG) $100 \mathrm{~g}$ a.i. ha $\mathrm{h}^{-1}$ at 35 DAS treated plot followed by clodinafoppropargyl $15 \%$ + metsulfuron $1 \%, 400 \mathrm{~g}$ a.i. ha ${ }^{-1} 35$ DAS. This may be due to lower dry weight of weed, which reduces the partitioning of nutrients. Weeds consume more nutrients than they need for their growth, and may accumulate higher mineral nutrient concentrations than crop plants (Kaur et al., 2018) ${ }^{[3]}$

The N, P and $\mathrm{K}$ depletion by weeds increased with increasing level of irrigation and significantly the highest depletion of nutrients (N, P and $\mathrm{K}$ ) by weeds were recorded under irrigation at $\mathrm{CRI}+$ jointing+booting+flowering+milking stage (Table 2). It could be attributed to the better soil moisture conditions, which helped in better utilization of nutrient by weeds, thereby resulting in highest weed dry weight and nutrient uptake (Verma et al., 2008 and Verma et al., 2015) [17, 21]. Weed management practices significant influenced on the $\mathrm{N}, \mathrm{P}$ and $\mathrm{K}$ depletion by weeds. It was significantly the highest under halauxafen - methyl $1.21 \% \mathrm{w} / \mathrm{w}$ + fluroxypyr at 35 DAS followed by sulfosulfuron $25 \mathrm{~g} \mathrm{ha}^{-1}$ at 35 DAS. The increase in the depletion of $\mathrm{N}, \mathrm{P}$ and $\mathrm{K}$ by weeds under this treatment was due to poor control of weeds resulted highest dry weight of weed, which corroborated with the findings of Singh et al. (2009) ${ }^{[14],}$ Kumar et al. (2017) ${ }^{[6]}$ and Singh et al. (2019) ${ }^{[13]}$.

\section{Nutrient content and their uptake by crop}

Increased irrigation frequency increased $\mathrm{P}$ content in grain and straw and it was the highest with irrigation at CRI+jointing+booting+flowering+milking stage due to the 
dilution effect (Table 1). Whereas, $\mathrm{N}$ and $\mathrm{K}$ content in grain and straw decreased with increased irrigation frequency and it was found the highest whean crop was irrigated at CRI+ active tillering stage $\left(\mathrm{I}_{1}\right)$. Results are in close conformity with the findings of Verma and Idnani (2012), ${ }^{[19]}$ Verma et al. (2013) ${ }^{[18]}$ and Kumar et al. (2017) ${ }^{[7]}$. An application of broadway (carfentrazone ethyl 20\% + sulfosulfuron $25 \% \mathrm{WG}$ ) $100 \mathrm{~g}$ a.i. ha ${ }^{-1}$ at $35 \mathrm{DAS}$ recorded significantly the highest $\mathrm{N}$, $\mathrm{P}$ and $\mathrm{K}$ content in grain and straw of wheat followed by clodinafop- propargyl $15 \%$ + metsulfuron $1 \%$, $400 \mathrm{~g}$ a.i. ha ${ }^{-1}$ 35 DAS, respectively.

Irrigation at CRI+jointing+booting+flowering+milking stage significantly influenced the $\mathrm{N}, \mathrm{P}$ and $\mathrm{K}$ uptake in grain and straw as well as total uptake of these nutrients by wheat (Table 2). It could be attributed to the better soil moisture conditions during plant growth which helped in better utilization of nutrient by the plant, thereby resulting in highest yield and nutrient uptake. It could be attributed to the better soil moisture conditions during growth period which helped in better utilization of nutrient by the plants, thereby resulting in highest yield and nutrient uptake. The similar results were also reported by Verma et al. $(2015)^{[21]}$.

Weed management practices significantly influenced the total $\mathrm{N}, \mathrm{P}$ and $\mathrm{K}$ uptake by wheat. It was significantly highest with post-emergence application of broadway (carfentrazone ethyl $20 \%$ + sulfosulfuron $25 \% \mathrm{WG}) 100 \mathrm{~g}$ a.i. ha ${ }^{-1}$ at 35 DAS over other herbicidal treatments. The increase in the uptake of nutrients by crop was due to the fact that lower dry weight of weeds under these treatments which helps in the better utilization of N, P and K, and other elements. The higher uptake of these nutrients was due to the higher yield, higher dry matter production and higher nutrient content in different parts of plants, which corroborated with the findings of Kumar et al. (2017) ${ }^{[7]}$, Singh et al. (2017) ${ }^{[16]}$ and Singh et al. (2019) ${ }^{[13]}$. Significantly the highest nutrients uptake was recorded under weed free situation due to higher grain and straw yield of wheat (Verma et al., 2015 and Paswan et al., 2017) ${ }^{[21,11]}$. This was due to reduced depletion of nutrients by weeds and concomitant increase in the absorption and translocation of these nutrients to different plant parts for enhanced photosynthetic efficiency (Khokhar and Nepalia, $2010^{[4]}$ and Verma et al., 2017) ${ }^{[20]}$. Herbicides application brought about significant reduction in $\mathrm{N}, \mathrm{P}$ and $\mathrm{K}$ uptake by weeds and enhanced their uptake by crop (Kumar et al. 2017) [6]. Monsefi et al. (2016) [9] and Singh et al. (2017) [15] reported that the nutrient uptake by crop decreased linearly with increase in nutrient removal by weeds.

\section{Available nutrients in soil}

The availability of $\mathrm{N}, \mathrm{P}, \mathrm{K}, \mathrm{S}$ and $\mathrm{Zn}$ in soil was higher with irrigation at CRI+ active tillering stage which was closely followed by irrigation at CRI + jointing + booting stage and it were significantly superior over $\left(\mathrm{I}_{4}\right)$ and $\left(\mathrm{I}_{3}\right)$, respectively. This may be due to fact that lower number of irrigation not fully utilized the available nutrients resulted increase in the availability of nutrients in soil. Similar results were also observed by reported by Verma et al. (2017) ${ }^{[20]}$ and Maurya et al. (2017) ${ }^{[8]}$.

All the weed management treatments recorded significantly the highest $\mathrm{N}, \mathrm{P}, \mathrm{K}, \mathrm{S}$ and $\mathrm{Zn}$ availability in soil than the weedy check. Weed free had more N, P, K, S and Zn availability in soil which was closely followed by broadway (carfentrazone- ethyl 20\% + sulfosulfuron 25\% WG) $100 \mathrm{~g}$ a.i. ha ${ }^{-1}$ at 35 DAS, clodinafop- propagyl $15 \%+$ metsulfuron $1 \% 400 \mathrm{~g}$ a.i. $\mathrm{ha}^{-1}$ at $35 \mathrm{DAS}$, pendimethalin (pre-em) $\mathrm{fb}$ WCPL-15 $400 \mathrm{~g} \mathrm{ha}^{-1}$ at 35 DAS, halauxafen + penxasulam $23.5 \% 75 \mathrm{~g}$ a.i. $\mathrm{ha}^{-1}$ at $35 \mathrm{DAS}$, sulfosulfuron $25 \mathrm{~g} \mathrm{ha}^{-1}$ at 35 DAS and halauxafen $1.21 \% \mathrm{w} / \mathrm{w}+$ fluroxpyr at 35 DAS (37.1 and $38.0 \mathrm{~g}$ ), respectively. Results are corroborated with the research results of Singh et al. (2017) ${ }^{[16]}$.

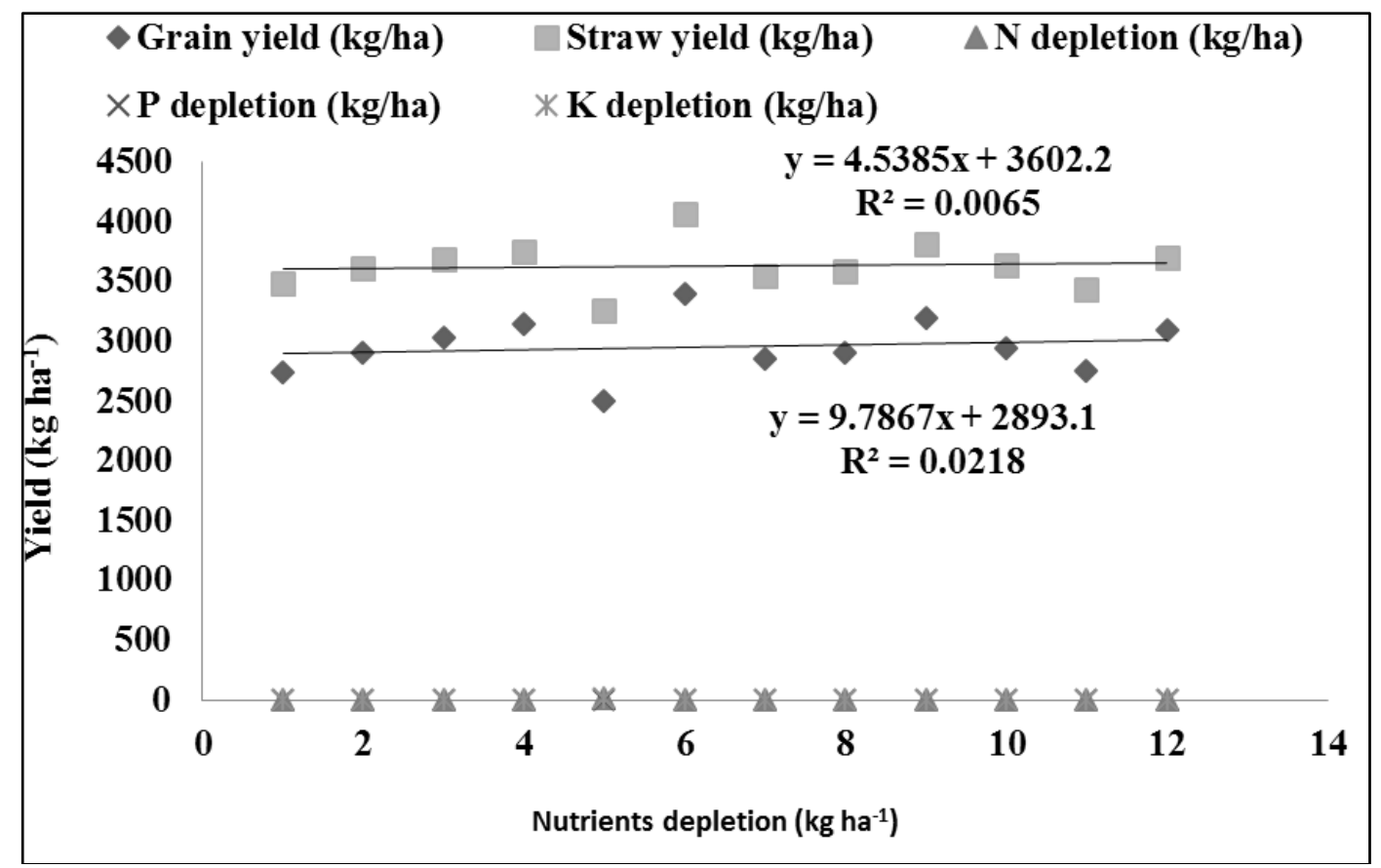

Fig 1: Relationship between nutrients depletion by weeds and yield 
Table 1: Effect of irrigation and weed management on weed dry weight, yield and nutrient concentration weeds and crop

\begin{tabular}{|c|c|c|c|c|c|c|c|c|c|c|c|c|}
\hline \multirow[t]{2}{*}{ Treatments } & \multirow{2}{*}{$\begin{array}{l}\text { Dry weight of weed } \\
\left(\mathrm{kg} \mathrm{ha}^{-1}\right)\end{array}$} & \multirow{2}{*}{$\begin{array}{c}\text { Grain } \\
\text { Yield } \\
\left(t^{\prime} \text { ha }^{-1}\right)\end{array}$} & \multirow{2}{*}{$\begin{array}{c}\text { Straw } \\
\text { yield } \\
\left(\mathrm{t} \mathrm{ha}^{-1}\right)\end{array}$} & \multicolumn{3}{|c|}{$\begin{array}{c}\text { Nutrient concentration in } \\
\text { weeds }(\%)\end{array}$} & \multicolumn{3}{|c|}{$\begin{array}{c}\text { Nutrient concentration in } \\
\text { wheat grain }(\%)\end{array}$} & \multicolumn{3}{|c|}{$\begin{array}{c}\text { Nutrient concentration } \\
\text { wheat straw }(\%)\end{array}$} \\
\hline & & & & $\mathbf{N}$ & $\mathbf{P}$ & $\mathbf{K}$ & $\mathbf{N}$ & $\mathbf{P}$ & $\mathbf{K}$ & $\mathbf{N}$ & $\mathbf{P}$ & $\mathbf{K}$ \\
\hline \multicolumn{13}{|c|}{ Irrigation schedule } \\
\hline $\mathrm{I}_{1}$ & 264.4 & 2737 & 3481 & 1.873 & 0.319 & 1.982 & 1.724 & 0.330 & 0.659 & 0.495 & 0.130 & 1.533 \\
\hline $\mathrm{I}_{2}$ & 317.4 & 2900 & 3613 & 1.872 & 0.319 & 1.982 & 1.722 & 0.332 & 0.659 & 0.491 & 0.132 & 1.532 \\
\hline $\mathrm{I}_{3}$ & 368.0 & 3037 & 3685 & 1.868 & 0.320 & 1.981 & 1.712 & 0.336 & 0.662 & 0.485 & 0.136 & 1.527 \\
\hline $\mathrm{I}_{4}$ & 389.7 & 3151 & 3748 & 1.868 & 0.321 & 1.980 & 1.710 & 0.337 & 0.659 & 0.483 & 0.138 & 1.525 \\
\hline SEm \pm & 24.9 & 46 & 30 & 0.003 & 0.002 & 0.001 & 0.017 & 0.005 & 0.007 & 0.020 & 0.002 & 0.009 \\
\hline $\mathrm{CD}(\mathrm{P}=0.05)$ & 70.1 & 146 & 97 & NS & NS & NS & NS & NS & NS & NS & $\mathrm{NS}$ & NS \\
\hline \multicolumn{13}{|c|}{ Weed management } \\
\hline $\mathrm{W}_{1}$ & 729.7 & 2506 & 3261 & 1.851 & 0.310 & 1.954 & 1.726 & 0.341 & 0.668 & 0.504 & 0.132 & 1.535 \\
\hline $\mathrm{W}_{2}$ & 000.0 & 3402 & 4068 & 1.878 & \begin{tabular}{|l|}
0.325 \\
\end{tabular} & 1.993 & 1.696 & 0.339 & 0.659 & 0.494 & 0.146 & 1.530 \\
\hline $\mathrm{W}_{3}$ & 362.2 & 2856 & 3544 & 1.869 & 0.319 & 1.984 & 1.722 & 0.334 & 0.661 & 0.486 & 0.135 & 1.530 \\
\hline $\mathrm{W}_{4}$ & 322.2 & 2911 & 3592 & 1.874 & 0.322 & 1.986 & 1.723 & 0.332 & 0.662 & 0.487 & 0.134 & 1.527 \\
\hline $\mathrm{W}_{5}$ & 276.3 & 3193 & 3815 & 1.876 & 0.323 & 1.984 & 1.705 & 0.328 & 0.652 & 0.483 & 0.130 & 1.523 \\
\hline $\mathrm{W}_{6}$ & 321.2 & 2946 & 3635 & 1.872 & 0.321 & 1.985 & 1.722 & 0.332 & 0.660 & 0.482 & 0.132 & 1.530 \\
\hline $\mathrm{W}_{7}$ & 365.5 & 2749 & 3433 & 1.868 & 0.318 & 1.982 & 1.725 & 0.338 & 0.665 & 0.492 & 0.134 & 1.533 \\
\hline $\mathrm{W}_{8}$ & 301.9 & 3093 & 3705 & 1.874 & 0.322 & 1.981 & 1.716 & 0.331 & 0.655 & 0.482 & 0.133 & 1.527 \\
\hline SEm \pm & 8.49 & 36 & 33 & 0.002 & 0.003 & 0.002 & 0.015 & 0.004 & 0.004 & 0.010 & 0.001 & 0.004 \\
\hline $\mathrm{CD}(\mathrm{P}=0.05)$ & 24.6 & 102 & 92 & 0.006 & 0.008 & 0.005 & NS & NS & NS & NS & NS & NS \\
\hline
\end{tabular}

$\mathrm{I}_{1}$-Two irrigation (CRI+active tillering), $\mathrm{I}_{2}$-Three irrigation (CRI+ jointing+booting), $\mathrm{I}_{3}-$ Four irrigation (CRI+active tillering+ booting+flowering), I4-Five irrigation (CRI+jointing+booting+flowering+milking), $\mathrm{W}_{1}$-Weedy check, $\mathrm{W}_{2}$ - Two hand weeding (20 and $40 \mathrm{DAS}$ ), $\mathrm{W}_{3}$-Sulfosulfuron@25 $\mathrm{g} \mathrm{ha}^{-1}$ at 35 DAS, W4- Pendimethalin (pre-em) $f b$ WCPL-15@400 g ha ${ }^{-1}$ at 35 DAS, W5- Broadway (carfentrazone ethyl 20\% + sulfosulfuron 25\%WG) @ $100 \mathrm{~g}$ a.i. ha $^{-1}$ at $35 \mathrm{DAS}, \mathrm{W}_{6}$ - Halauxafen + penxasulam 23.5\% @ $75 \mathrm{~g}$ a.i. ha ${ }^{-1}$ at $35 \mathrm{DAS} \mathrm{W}_{7-}$ Halauxafen methyl 1.21\% w/w + fluroxypyr @ at 35 DAS, W8- Clodinafop- propargyl 15\% + metsulfuron 1\% @ 400 g a.i. ha ${ }^{-1} 35 \mathrm{DAS}^{-1}$

Table 2: Effect of irrigation and weed management on weed dry weight, yield and nutrient concentration weeds and crop

\begin{tabular}{|c|c|c|c|c|c|c|c|c|c|c|c|}
\hline \multirow[t]{2}{*}{ Treatments } & \multicolumn{3}{|c|}{$\begin{array}{l}\text { Nutrients depletion by } \\
\text { weeds }\left(\mathrm{kg} \mathrm{ha}^{-1}\right)\end{array}$} & \multicolumn{3}{|c|}{$\begin{array}{c}\text { Nutrient uptake by crop } \\
\left(\mathrm{kg} \mathrm{ha}^{-1}\right)\end{array}$} & \multicolumn{5}{|c|}{$\begin{array}{l}\text { Available nutrient } \\
\text { in soil }\end{array}$} \\
\hline & $\mathbf{N}$ & $\mathbf{P}$ & $\mathbf{K}$ & $\mathbf{N}$ & $\mathbf{P}$ & $\mathbf{K}$ & $\mathrm{N}\left(\mathrm{kg} \mathrm{ha}^{-1}\right)$ & $\mathbf{P}\left(\mathrm{kg} \mathrm{ha}^{-1}\right)$ & $\mathrm{K}\left(\mathrm{kg} \mathrm{ha}^{-1}\right)$ & $S\left(\mathrm{~kg} \mathrm{ha}^{-1}\right)$ & $\mathrm{Zn}\left(\mathrm{mg} \mathrm{kg}{ }^{-1}\right)$ \\
\hline \multicolumn{12}{|l|}{ Irrigation schedule } \\
\hline $\mathrm{I}_{1}$ & 4.94 & 0.84 & 5.22 & 63.1 & 13.15 & 67.10 & 168.35 & 11.82 & 153.40 & 15.77 & 0.561 \\
\hline $\mathrm{I}_{2}$ & 5.93 & 1.01 & 6.27 & 66.2 & 14.00 & 69.75 & 167.50 & 11.75 & 152.80 & 15.70 & 0.559 \\
\hline $\mathrm{I}_{3}$ & 6.86 & 1.17 & 7.27 & 68.3 & 14.80 & 71.55 & 166.35 & 11.62 & 151.45 & 15.68 & 0.556 \\
\hline $\mathrm{I}_{4}$ & 7.26 & 1.24 & 7.70 & 70.7 & 15.40 & 73.70 & 166.30 & 11.65 & 151.65 & 15.66 & 0.557 \\
\hline SEm \pm & 0.47 & 0.08 & 0.49 & 0.9 & 0.22 & 0.68 & 0.30 & 0.03 & 0.25 & 0.02 & 0.001 \\
\hline $\mathrm{CD}(\mathrm{P}=0.05)$ & 1.30 & 0.22 & 1.37 & 2.7 & 0.66 & 2.03 & 0.93 & 0.08 & 0.80 & 0.06 & 0.003 \\
\hline \multicolumn{12}{|c|}{ Weed management } \\
\hline $\mathrm{W}_{1}$ & 13.50 & 2.26 & 14.25 & 57.6 & 12.30 & 60.60 & 165.10 & 11.51 & 150.50 & 15.54 & 0.553 \\
\hline $\mathrm{W}_{2}$ & 0.00 & 0.00 & 0.00 & 76.2 & 17.00 & 79.75 & 169.65 & 11.93 & 154.15 & 15.89 & 0.564 \\
\hline $\mathrm{W}_{3}$ & 6.77 & 1.16 & 7.18 & 64.9 & 13.92 & 68.40 & 166.30 & 11.63 & 151.55 & 15.65 & 0.555 \\
\hline $\mathrm{W}_{4}$ & 6.03 & 1.04 & 6.39 & 66.7 & 14.22 & 71.25 & 167.25 & 11.73 & 152.45 & 15.69 & 0.559 \\
\hline $\mathrm{W}_{5}$ & 5.18 & 0.90 & 5.48 & 71.6 & 15.07 & 74.80 & 168.05 & 11.81 & 153.35 & 15.75 & 0.562 \\
\hline $\mathrm{W}_{6}$ & 6.01 & 1.03 & 6.37 & 67.1 & 14.28 & 71.60 & 166.85 & 11.69 & 152.15 & 15.68 & 0.557 \\
\hline $\mathrm{W}_{7}$ & 6.83 & 1.16 & 7.24 & 62.5 & 13.40 & 65.30 & 166.10 & 11.61 & 151.35 & 15.69 & 0.555 \\
\hline $\mathrm{W}_{8}$ & 5.66 & 0.97 & 5.98 & 69.7 & 14.78 & 72.70 & 167.70 & 11.77 & 153.00 & 15.72 & 0.561 \\
\hline SEm \pm & 0.26 & 0.05 & 0.28 & 0.6 & 0.10 & 0.69 & 0.28 & 0.02 & 0.21 & 0.02 & 0.001 \\
\hline $\mathrm{CD}(\mathrm{P}=0.05)$ & 0.83 & 0.15 & 0.89 & 2.0 & 0.31 & 2.06 & 0.79 & 0.06 & 0.57 & 0.05 & 0.002 \\
\hline Initial value & - & - & - & - & - & - & 172.45 & 12.85 & 156.50 & 15.75 & 0.547 \\
\hline
\end{tabular}

$\mathrm{I}_{1}$-Two irrigation (CRI+active tillering), $\mathrm{I}_{2}$-Three irrigation (CRI+ jointing+booting), $\mathrm{I}_{3}-$ Four irrigation (CRI+active tillering+ booting+flowering), $\mathrm{I}_{4}$-Five irrigation (CRI+jointing+booting+flowering+milking), $\mathrm{W}_{1}$-Weedy check, $\mathrm{W}_{2}$ - Two hand weeding (20 and $40 \mathrm{DAS}$ ), $\mathrm{W}_{3}$-Sulfosulfuron @ $25 \mathrm{~g} \mathrm{ha}^{-1}$ at 35 DAS, W4- Pendimethalin (pre-em) $f b$ WCPL-15@ $400 \mathrm{~g} \mathrm{ha}^{-1}$ at 35 DAS, W5- Broadway (carfentrazone ethyl

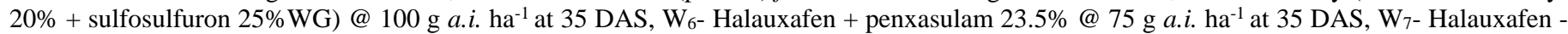
methyl 1.21\% w/w + fluroxypyr @ at 35 DAS, W8- Clodinafop- propargyl 15\% + metsulfuron 1\% @ 400 g a.i. ha ${ }^{-1} 35 \mathrm{DAS}^{2}$

\section{References}

1. Dhaliwal LK, Buttar GS, Kingra PK, Kaur S, Singh J. Growth, yield, water use efficiency of wheat under different sowing dates, planting methods and irrigation treatments. Ind. J Agric. Sci. 2020; 90(3):519-523.

2. Kaur A, Singh S. Performance of different herbicides on wheat grain yield and correlation between growth and yield attributes of wheat and weeds Indian J Weed Sci. 2019; 51(2):129-132.

3. Kaur S, Kaur R, Chauhan BS. Understanding crop-weedfertilizer-water interactions and their implications for weed management in agricultural systems. Crop Prote. 2018; 103:65-72.

4. Khokhar AK, Nepalia V. Effect of herbicides and nutrient management on weed flora, nutrient uptake and yield of wheat. Ind. J Weed Sci. 2010; 42:14-18.

5. Kumar R, Singh UP, Mahajan G. Influence of residue and weed management practices on no-till wheat under rice-wheat cropping system. Indian J Soil Cons. 2017; 45(2):198-202.

6. Kumar S, Agrawal KK, Kewat ML, Kumhar BL. Effect of post emergence herbicides on yield and economics of 
wheat. The Pharma Innovation Journal. 2019; 8(7):602604.

7. Kumar S, Sharma PK, Yadav MR, Sexena R, Gupta KC, Kumar $\mathrm{R}$ et al. Effect of irrigation levels and moisture conserving polymers on growth, productivity and profitability of wheat. Indian Journal of Agricultural Sciences. 2019; 89(3):509-14.

8. Maurya AC, Verma SK, Kumar S, Lakra K. Nutrient concentration and their uptake and available nutrients in soil influenced by irrigation, mulching and integrated nutrient management in summer groundnut. Int. J Curr. Microbiol. App. Sci. 2017; 6(11):2405-2415.

9. Monsefi A, Sharma AR, Zan NR. Weed management and conservation tillage for improving productivity, nutrient uptake and profitability of wheat in soybean -wheat cropping system. Int. Journal of Plant Production. 2016; 10(1):1-12.

10. Nadeem MA, Tanveer A, Ali A, Ayub M, Tahir M. Effect of weed control practices and irrigation levels on weeds and yield of wheat. Ind. J Agron. 2010; 55:60-63.

11. Paswan AK, Mandal D, Kumawat N, Kumar J, Kumar R, Singh AK, Kumar A et al. Efficacy of separate and premix formulation of metsulfuron-methyl and carfentrazone-ethyl on weeds in wheat: a review. Int. J Curr. Microbiol. App. Sci. 2017; 6(7):2439-2453.

12. Sangwan M, Hooda VS, Singh J, Duhan A. Herbicidal weed management in dual purpose tall wheat. Ind. J Agric. Sci. 2019; 89(9):1509-1512.

13. Singh $M$, Singh $O$, Singh R. Impact of wheat establishment methods and weed management practices on weed flora, yield and nutrient uptake of wheat in ricewheat cropping system. Journal of Agri-Search. 2019; 6(2):73-77.

14. Singh RK, Verma SK, Sharma R, Singh SB. Bio-efficacy and selectivity of Sulfosulfuron and metribuzin before and after irrigation in wheat under zero tillage system. Ind. J Agric. Sci. 2009; 79(9):735-739.

15. Singh RP, Verma SK, Kumar S. Crop establishment methods and weed management practices affects crop growth, yield, nutrients uptake and weed dynamics in wheat. International Journal of Bio-resource and Stress Management. 2017; 8(3):393-400.

16. Singh RP, Verma SK, Kumar S, Lakra K. Impact of tillage and herbicides on the dynamics of broad leaf weeds in wheat. Int. J Agri., Env. and Biotechnology. 2017; 10(6):643-651.

17. Verma SK, Singh SB, Rai OP, Sharma R, Singh G. Effect of cultivars and herbicides on yield and nutrient uptake by weed and wheat under zero-tillage system. Indian Journal of Agricultural Sciences. 2008; 78(11):985-989.

18. Verma SK, Kumar A, Idnani LK. Effect of irrigation and nitrogen management on growth and yield of potato and their residual effect on succeeding maize under potatomaize cropping system. Indian Journal of Agronomy. 2013; 58(1):48-53.

19. Verma SK, Idnani LK. Water use, nutrient content and their uptake as influenced by irrigation and nitrogen management in potato-maize cropping system. Ind. J Agri. Sci. 2012; 82(12):1032-1038.

20. Verma SK, Singh RP, Kumar S. Effects of irrigation and herbicides on the growth, yield and yield attributes of wheat. Bangladesh J Bot. 2017; 46(3):839-845.

21. Verma SK, Singh SB, Prasad SK, Meena RN, Meena RS. Influence of irrigation regimes and weed management practices on water use and nutrient uptake in wheat. Bangladesh J Bot. 2015; 44(3):437-442.

22. Zargar M, Bayat M, Astarkhanova T. Study of postemergence-directed herbicides for redroot pigweed control in winter wheat in southern Russia. Journal of Plant Protection Research. 2020; 60(1):7-13. 